\title{
HFC-152a and HFC-134a emission estimates and characterization of CFCs, CFC replacements, and other halogenated solvents measured during the 2008 ARCTAS campaign (CARB phase) over the South Coast Air Basin of California
}

\author{
B. Barletta ${ }^{1}$, P. Nissenson ${ }^{2}$, S. Meinardi ${ }^{1}$, D. Dabdub ${ }^{2}$, F. Sherwood Rowland ${ }^{1}$, R. A. VanCuren ${ }^{3}$, J. Pederson ${ }^{3}$, \\ G. S. Diskin ${ }^{4}$, and D. R. Blake ${ }^{1}$ \\ ${ }^{1}$ Department of Chemistry, University of California-Irvine, Irvine, 92697 CA, USA \\ ${ }^{2}$ Department of Mechanical and Aerospace Engineering, The Henry Samueli School of Engineering, University of \\ California-Irvine, Irvine, 92697 CA, USA \\ ${ }^{3}$ Research Division, California Air Resources Board, Sacramento, 95812 CA, USA \\ ${ }^{4}$ NASA Langley Research Center, Hampton, 23681 VA, USA
}

Received: 19 October 2010 - Published in Atmos. Chem. Phys. Discuss.: 16 November 2010

Revised: 22 February 2011 - Accepted: 7 March 2011 - Published: 22 March 2011

\begin{abstract}
This work presents results from the NASA Arctic Research of the Composition of the Troposphere from Aircraft and Satellites (ARCTAS) study. Whole air samples were obtained on board research flights that flew over California during June 2008 and analyzed for selected volatile organic compounds, including several halogenated species. Samples collected over the South Coast Air Basin of California (SoCAB), which includes much of Los Angeles (LA) County, were compared with samples from inflow air masses over the Pacific Ocean. The levels of many halocarbon species were enhanced significantly over the SoCAB, including compounds regulated by the Montreal Protocol and subsequent amendments. Emissions estimates of HFC-152a (1,1-difluoroethane, $\mathrm{CH}_{3} \mathrm{CHF}_{2}$; $0.82 \pm 0.11 \mathrm{Gg})$ and HFC-134a (1,1,1,2-tetrafluoroethane, $\mathrm{CH}_{2} \mathrm{FCF}_{3} ; 1.16 \pm 0.22 \mathrm{Gg}$ ) in LA County for 2008 were obtained using the observed HFC:carbon monoxide (CO) enhancement ratio. Emission rates also were calculated for the SoCAB $\left(1.60 \pm 0.22 \mathrm{Gg} \mathrm{yr}^{-1}\right.$ for HFC-152a and $2.12 \pm 0.28 \mathrm{Gg} \mathrm{yr}^{-1}$ for HFC-134a) and then extrapolated to the United States $\left(32 \pm 4 \mathrm{Gg} \mathrm{yr}^{-1}\right.$ for HFC-152a and $43 \pm 6 \mathrm{Gg} \mathrm{yr}^{-1}$ for HFC-134a) using population data. In addition, emission rates of the two HFCs in LA County and SoCAB were calculated by a second method that utilizes air
\end{abstract}

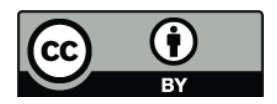

Correspondence to: B. Barletta (bbarlett@uci.edu) quality modeling. Emissions estimates obtained using both methods differ by less than $25 \%$ for the LA County and less than $45 \%$ for the SoCAB.

\section{Introduction}

Chlorofluorocarbon (CFC) compounds are used in a variety of applications including refrigeration, air conditioning, foam blowing, and as aerosol propellants (Sturrock et al., 2002; McCulloch et al., 2003). The harmful impact of CFCs on stratospheric ozone has led to their phase-out governed by the regulations in the Montreal Protocol and subsequent amendments (UNEP, 2003; WMO, 2007). A phase-out for the production and consumption of CFCs, methyl chloroform $\left(\mathrm{CH}_{3} \mathrm{CCl}_{3}\right)$, halons, and carbon tetrachloride $\left(\mathrm{CCl}_{4}\right)$ was imposed in developed countries in 1996 (although exceptions exist for critical and non-dispersive uses), and a global ban was scheduled for 2010 (2015 for $\mathrm{CH}_{3} \mathrm{CCl}_{3}$; UNEP, 2003). Methyl chloroform was used as an industrial cleaner and degreaser (McCulloch, 2001), halons were used in fire-fighting (Butler et al., 1998), and $\mathrm{CCl}_{4}$ was a solvent and chemical intermediate for CFC production (Altshuller, 1976; Sturrock et al., 2002). Other halogenated compounds discussed in this study are used in the industrial sector, mainly as solvents and degreasers (methylene chloride, $\mathrm{CH}_{2} \mathrm{Cl}_{2}$; chloroform, $\mathrm{CHCl}_{3}$; trichloroethane, $\mathrm{C}_{2} \mathrm{HCl}_{3}$; and tetrachloroethene, $\mathrm{C}_{2} \mathrm{Cl}_{4}$ ). 
Hydrochlorofluorocarbons (HCFCs) and hydrofluorocarbons (HFCs) were introduced as substitutes for CFC compounds. HCFCs are used in air conditioning, refrigeration, and foam plastic applications (McCulloch et al., 2003). They still contribute to the destruction of stratospheric ozone and are considered to be a transitional species; HCFC consumption and production were frozen in developed countries in 1996 and 2004, respectively (2013 for developing countries), and a $100 \%$ global phase-out is mandated by 2040 (EC, 2008). HFCs are being introduced as replacement compounds for both CFCs and HCFCs since they do not harm stratospheric ozone. However, HFCs typically exhibit high global warming potentials (GWP) because of their ability to absorb infrared radiation and relatively long lifetimes ( years). The GWPs (100-yr time horizon) for the two HFCs investigated in this study, HFC134a (1,1,1,2-tetrafluoroethane, $\left.\mathrm{CH}_{2} \mathrm{FCF}_{3}\right)$ and HFC-152a (1,1-difluoroethane, $\mathrm{CH}_{3} \mathrm{CHF}_{2}$ ), are 1430 and 124, respectively (Forster et al., 2007). The high GWP for HFC-134a has led to the European Union phasing out this species in new vehicles in 2011 with a total ban in 2017 (EP, 2006). HFC-134a is the main refrigerant used in car air conditioners (McCulloch et al., 2003) and is the most abundant HFC in the atmosphere with an estimated background concentration of $43.5 \pm 0.2 \mathrm{ppt}$ in 2008 (based on the average of the lowest quartile of the inflow samples from this study, discussed in Sect. 3.1). HFC-152a is used mainly as a foam-blowing agent and in aerosol spray applications, and is a possible alternative to HFC-134a in car air-conditioning systems due to its lower GWP. While background levels of HFC-152a are relatively low, $6.1 \pm 0.4 \mathrm{ppt}$ in 2008 (based on the average of the lowest quartile of the inflow samples from this study, discussed in Sect. 3.1), atmospheric levels of this compound are increasing exponentially primarily because of emissions in North America (Stohl et al., 2009, and references therein).

Emissions estimates of halogenated compounds often are obtained through "bottom-up" methods based on production and consumption/usage data. However, the uncertainties of government and industry reports can affect these estimates significantly. Additionally, production data are lacking for species produced by a limited number of manufacturers. This study uses a different approach (i.e., "top-down" methods) to determine emissions estimates using atmospheric measurements.

The NASA Arctic Research of the Composition of the Troposphere from Aircraft and Satellites (ARCTAS) study was conducted in two deployments (ARCTAS-A during April 2008 and ARCTAS-B during June-July 2008) and utilized DC-8, P-3, and B-200 aircrafts. Before the second deployment, four research flights on board the NASA DC-8 aircraft were sponsored by the California Air Resources Board (CARB) in June 2008. These four flights focused on the characterization of the atmosphere over California and conducted many low altitude passes over significant pollution source regions, including the San Joaquin Valley and South Coast
Air Basin (SoCAB). The main objectives of the California deployment (ARCTAS-CARB) are the improvement of state emission inventories for greenhouse gases and aerosols, the characterization of offshore pollutants from shipping and natural sources, and the characterization of upwind boundary conditions for modeling local surface ozone and $\mathrm{PM}_{2.5}$. A general overview of the mission design and scientific themes of the ARCTAS and CARB flights are discussed in Jacob et al. (2010) and can be found in the official ARCTAS website (ARCTAS, 2011).

Whole air samples were collected on board the DC-8 and analyzed for selected volatile organic compounds (VOCs). This study focuses on selected halocarbon species collected over the SoCAB, with special attention to the area around Los Angeles (LA). The SoCAB contains the largest urban area in the western United States with a population of over 15 million living in an area that is approximately $160 \mathrm{~km}$ long and $100 \mathrm{~km}$ wide (SCAQMD, 2008). It includes all of Orange County and the western, urbanized portions of Los Angeles, Riverside, and San Bernardino Counties. The basin forms a low plain flanked by the Pacific Ocean to the west and surrounded on the other sides by mountains which channel and confine air masses.

Although previous studies use top-down methods to estimate HFC emissions (Yokouchi et al., 2006; Greally et al., 2007; Millet et al., 2009), report emissions of HFCs (Reimann et al., 2002, 2004; Buchmann et al., 2003; Maione et al., 2008; Kim et al., 2010) and emissions of regulated CFCs and other halogenated compounds in North America (Hurst et al., 2006; Millet et al., 2009; Barletta et al., 2009), this study is the first time that halocarbons from the SoCAB are examined and compared to samples obtained from relatively clean inflow air masses. This work makes an important contribution to understanding the tropospheric composition of a highly urbanized and industrialized region, such as the SoCAB, through the characterization and quantification of several halogenated species. These species include selected greenhouse gases that are used extensively in California (i.e., $\mathrm{CFC}$ replacement compounds) and species regulated by the Montreal Protocol and subsequent amendments, including CFCs. Accurate knowledge of halocarbon levels in the atmosphere allows policymakers to assess the effectiveness of mitigation strategies.

Additionally, estimates of the HFC-152a and HFC-134a emission rate from LA County and the SoCAB during 2008 are obtained using two methods: (1) In the "tracer ratio" method, atmospheric measurements of the HFC:carbon monoxide (CO) ratio are combined with the reported $\mathrm{CO}$ emission rates for 2008. The HFC-152a and HFC-134a emission rate estimates calculated for the SoCAB are extrapolated to the US using population data; (2) In the "AQM" method, an air quality model of the SoCAB is employed to calculate the emission rate needed to reproduce field measurements obtained during the ARCTAS-CARB campaign. The emission rates used in the model are adjusted incrementally until 
the levels from the simulations match the field measurement data.

\section{Analysis and distribution of volatile organic compounds}

\subsection{Collection and analysis of air samples}

During the four flights of ARCTAS-CARB a total of 617 whole air samples were collected in 2-L electropolished stainless steel canisters equipped with a Swagelok metal bellows valve on board four flights in a DC-8 aircraft. The canisters were flushed with ultra-high purity (UHP) helium and then evacuated to $10^{-2}$ Torr in a laboratory at the University of California, Irvine (UC Irvine) prior to shipment to the field. Seventeen Torr of degassed ultrapure Milli$\mathrm{Q}$ water was added to the canisters in order to passivate the surface of the internal walls, minimizing the absorbance of selected compounds inside the canisters. During each sampling, which lasts approximately one minute, the canisters were pressurized to $40 \mathrm{psi}$ using a metal double bellows pump. Canisters were filled at $1-3 \mathrm{~min}$ intervals during ascents and descents, and every $2-8$ min during horizontal flight legs. A maximum of 168 canisters were filled for each flight on the DC-8. After each flight, the canisters were shipped back to the laboratory at UC Irvine and the contents analyzed within seven days of sample collection for more than 75 gases, including non-methane hydrocarbons, halocarbons, alkyl nitrates, sulfur compounds, and oxygenated compounds.

The analytical system used in this study is similar to the system described in Colman et al. (2001). Briefly, $2440 \pm 3 \mathrm{~cm}^{3}$ (STP) of an air sample is pre-concentrated in a stainless steel loop filled with glass beads and submerged in liquid nitrogen. The sample is heated to approximately $80^{\circ} \mathrm{C}$ and split into six different column/detector combinations housed in three gas chromatographs (GCs) using UHP helium as the carrier gas: (1) DB-1 column (J\&W; $60 \mathrm{~m}, 0.32 \mathrm{~mm}$ I.D., $1 \mu \mathrm{m}$ film thickness) output to a flame ionization detector (FID); (2) DB-5 column (J\&W; $30 \mathrm{~m}, 0.25 \mathrm{~mm}$ I.D., $1 \mu \mathrm{m}$ film thickness) connected in series to a RESTEK 1701 column ( $5 \mathrm{~m}, 0.25 \mathrm{~mm}$ I.D., $0.5 \mu \mathrm{m}$ film thickness) and output to an electron capture detector (ECD); (3) RESTEK 1701 column (60 m, 0.25 mm I.D., $0.50 \mu \mathrm{m}$ film thickness) output to an ECD; (4) PLOT column (J\&W GS-Alumina; $30 \mathrm{~m}, 0.53 \mathrm{~mm}$ I.D.) connected in series to a DB-1 column (J\&W; $5 \mathrm{~m}, 0.53 \mathrm{~mm}$ I.D., $1.5 \mu \mathrm{m}$ film thickness) and output to an FID; (5) DB-5ms column (J\&W; $60 \mathrm{~m}, 0.25 \mathrm{~mm}$ I.D., $0.5 \mu \mathrm{m}$ film thickness) output to a nitrogen phosphorus detector (NPD); (6) DB-5ms column (J\&W; $60 \mathrm{~m}, 0.25 \mathrm{~mm}$ I.D., $0.5 \mu \mathrm{m}$ film thickness) output to a quadrupole mass spectrometer detector (MSD, HP 5973). The MSD is set to operate in selected ion monitoring (SIM) mode with one ion chosen to quantify each compound in or- der to achieve the maximum selectivity and to avoid potential interferences. All gas chromatographs and detectors used in this study are manufactured by Hewlett Packard.

The precision of the measurements varies by compound and by mixing ratio: $1 \%$ for the $\mathrm{CFCs}$ and $\mathrm{CCl}_{4} ; 2 \%$ for the HCFCs; $5 \%$ for HFC-134a and $\mathrm{CH}_{2} \mathrm{Cl}_{2} ; 10 \%$ for HFC152a; 2\% for Halon-1211 (Bromochlorodifluoromethane, $\mathrm{CBrClF}_{2}$ ), methyl halides, $\mathrm{CH}_{3} \mathrm{CCl}_{3}, \mathrm{C}_{2} \mathrm{Cl}_{4}$, and bromoform $\left(\mathrm{CHBr}_{3}\right)$. The measurement accuracy also varies by compound: $2 \%$ for all CFCs except CFC-114 (1,2dichloro-1,1,2,2-tetrafluoroethane, $\mathrm{C}_{2} \mathrm{Cl}_{2} \mathrm{~F}_{4}$ ), which is 5\%; $10 \%$ for the HCFCs, HFC-152a, $\mathrm{C}_{2} \mathrm{Cl}_{4}, \mathrm{CH}_{2} \mathrm{Cl}_{2}$, methyl iodide $\left(\mathrm{CH}_{3} \mathrm{I}\right)$ and $\mathrm{CHBr}_{3} ; 5 \%$ for halons, HFC-134a, $\mathrm{CH}_{3} \mathrm{CCl}_{3}, \mathrm{CCl}_{4}$, methyl chloride $\left(\mathrm{CH}_{3} \mathrm{Cl}\right)$, and methyl bromide $\left(\mathrm{CH}_{3} \mathrm{Br}\right)$.

Original standards for HFCs were from Scott-Marrin in the range of $10-300 \mathrm{ppb}$ (nominal). These are checked against a butane/benzene NIST (National Institute of Standards and Technology) standard with an atomic emission detector. Dynamic dilutions of the high concentration standards and injection of variable volumes of these dilutions provided a calibration curve in the range of ambient concentrations. High pressure tanks were prepared by dilution of the high concentration tanks (also from Scott-Marrin). These tanks were used for more frequent comparisons and then also checked against the high concentration tank by dynamic dilution. After the initial addition of 17 Torr of degassed ultrapure Milli$\mathrm{Q}$ water the air is transferred from the cylinder to an electropolished stainless steel pontoon $(34 \mathrm{~L})$ equipped with a Swagelok metal bellows valve. A higher degree of stability inside the electropolished stainless steel pontoon compared to storage in an aluminum cylinder has been determined for higher molecular weight hydrocarbons, alkyl nitrate, sulfur species and some of the halocarbons. During the analysis a working standard is analyzed every eight samples, and a series of different standards, including primary standards, is analyzed once a day.

CO was measured in situ on the DC- 8 by a differential absorption CO measurement (DACOM) instrument (Sachse et al., 1987). The HFC:CO ratio, along with CO emissions data, is used to determine the HFC-152a and HFC-134a emission rate in the LA area and SoCAB (see Sect. 3.2.1).

\subsection{Distribution of ARCTAS-CARB air samples}

The 617 air samples obtained on board four DC-8 flights during the ARCTAS-CARB campaign were collected both over California and off the California coast. An additional 139 air samples were collected over California on board two transit flights from California to Cold Lake, Canada (Flights 16 and 24), where the DC-8 was stationed for the second phase of ARCTAS. The majority of the samples were collected at low altitude during the daytime as illustrated in Fig. 1 and Table 1. Air samples were collected over two main source regions: the San Joaquin Valley (SJV) and South Coast Air 
Table 1. Statistics of air samples collected over California and off the California coast during the four ARCTAS-CARB flights and two transit flights.

\begin{tabular}{lccc}
\hline Flight Date (Flight \#) & Number of samples & Altitude Range $(\mathrm{km})$ & Sampling Time Range** $^{*}$ \\
\hline $06 / 18 / 2008(\# 12)$ & 152 & $0.08-4.5$ & $08: 38-14: 34$ \\
$06 / 20 / 2008(\# 13)$ & 165 & $0.29-6.7$ & $10: 43-18: 12$ \\
$06 / 22 / 2008(\# 14)$ & 168 & $0.08-9.1$ & $08: 17-17: 19$ \\
$06 / 24 / 2008(\# 15)$ & 132 & $0.15-9.1$ & $09: 43-17: 17$ \\
$06 / 26 / 2008(\# 16)^{*}$ & 51 & $0.32-5.3$ & $07: 31-09: 29$ \\
$07 / 13 / 2008(\# 24)^{*}$ & 88 & $0.34-4.0$ & $13: 10-15: 43$ \\
Total & 756 & & \\
\hline
\end{tabular}

* Includes only the samples collected over California;

** Local Time.

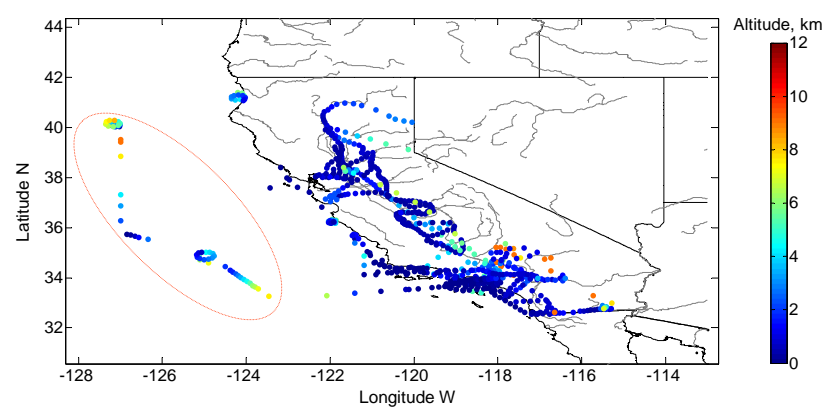

Fig. 1. Geographic distribution of samples collected during the four ARCTAS-CARB flights and two transit flights. The samples are color-coded by altitude. The dotted red oval highlights part of the samples collected during Flight 14, which are used to characterize the inflow air.

Basin (SoCAB). Low-level passes around the San Diego area and along the border between the United States and Mexico occurred during Flights 12 and 15, respectively. This work examines only the field measurements obtained over the So$\mathrm{CAB}$ and in the inflow air masses over the Pacific Ocean.

Among the 756 canisters collected over California, 196 were obtained over the SoCAB (outlined by a solid gray line in Fig. 2). A subset (90 samples) of the SoCAB samples was obtained over the LA area (outlined by a red dashed line in Fig. 2). The LA area samples were collected at an average altitude of $1.1 \pm 1.3 \mathrm{~km}$, with more than $80 \%$ of the canisters (75 out of 90$)$ filled below $2 \mathrm{~km}$ and only 11 samples ( $10 \%$ ) above $3 \mathrm{~km}$. The average sampling altitude over the SoCAB was $1.0 \pm 1.4 \mathrm{~km}$.

A polluted air mass can be transported far from its origin making the source identification difficult. The use of backward trajectories is a useful and common tool for investigating the movement of air masses. For instance, kinematic back trajectories, in conjunction with a detailed characterization of the composition of pollution plumes, were used in documenting the impact of Asian outflow on North Amer-

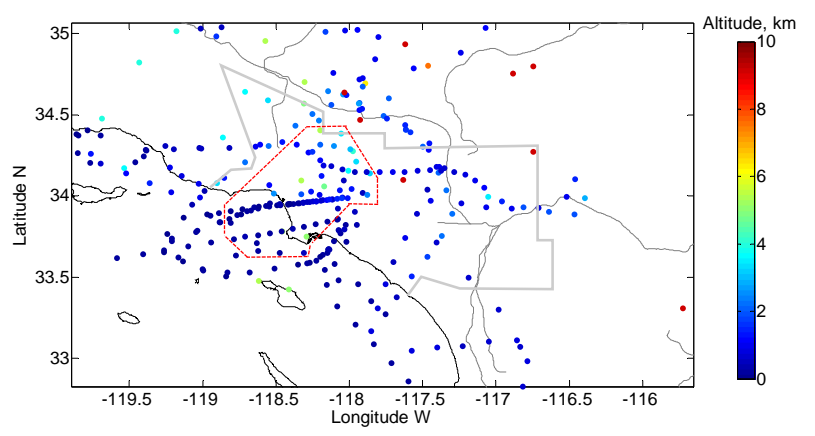

Fig. 2. Geographic distribution of samples collected over Southern California. The SoCAB is indicated by the solid grey line and samples obtained within the LA area are included within the red dashed line.

ica (i.e. Liu et al., 2003; Barletta et al., 2009). However, the influence of sources located far away from the collection site can be neglected if air masses are sampled within the planetary boundary layer or at altitudes low enough to suggest minimum mixing of freshly emitted pollution plumes with free tropospheric air affected by transported air pollution (Millet et al., 2009). Therefore, the authors assume that measured pollutant concentrations were due primarily to local sources, not transported air masses.

\section{Discussion}

\subsection{General trend in halocarbons in the LA area and SoCAB}

In order to establish the contribution from local sources to halocarbon levels measured over the LA area and SoCAB, the inflow concentrations of halocarbon species were determined from a set of 60 air samples collected about 250$450 \mathrm{~km}$ offshore during Flight 14 along a south to north leg over the Pacific Ocean (Fig. 1). These samples contained air moving toward California with minimal North American 
Table 2. Data from air samples obtained in the inflow air mass, over the LA area, and over the SoCAB during the ARCTAS-CARB flights. Data in parts per trillion by volume, unless otherwise specified (indicated as "ppt" throughout the paper).

\begin{tabular}{|c|c|c|c|c|c|c|c|c|c|c|c|}
\hline & \multicolumn{3}{|c|}{ Inflow $(n=60)$} & \multicolumn{4}{|c|}{$\operatorname{SoCAB}(n=106)$} & \multicolumn{4}{|c|}{ LA area $(n=90)$} \\
\hline & $\begin{array}{c}\text { Range } \\
\text { (Min-Max) }\end{array}$ & Mean & SD & $\begin{array}{c}\text { Range } \\
\text { (Min-Max) }\end{array}$ & Mean & $\mathrm{SD}$ & $\begin{array}{c}\% \text { High } \\
\text { samples* }\end{array}$ & $\begin{array}{c}\text { Range } \\
\text { (Min-Max) }\end{array}$ & Mean & SD & $\begin{array}{l}\% \text { High } \\
\text { samples* }\end{array}$ \\
\hline \multicolumn{12}{|l|}{ CFCs } \\
\hline CFC-12 & $520-534$ & 528 & 4 & $523-654$ & 541 & 13 & 73 & $523-564$ & 539 & 9 & 69 \\
\hline CFC-11 & $240-250$ & 245 & 2 & $241-498$ & 259 & 27 & 79 & $242-394$ & 258 & 21 & 76 \\
\hline CFC-113 & $74.4-78.6$ & 76.3 & 0.8 & $75.3-82.7$ & 77.9 & 1.1 & 37 & $75.3-80.7$ & 78.1 & 1.0 & 60 \\
\hline CFC-114 & $15.5-16.5$ & 16.1 & 0.2 & $15.5-16.8$ & 16.3 & 0.3 & 33 & $15.7-16.8$ & 16.3 & 0.2 & 28 \\
\hline \multicolumn{12}{|l|}{ HCFCs } \\
\hline HCFC-22 & $186-240$ & 201 & 10 & $186-926$ & 280 & 107 & 66 & 186.4-926 & 276 & 100 & 62 \\
\hline HCFC-142b & $18.4-23.7$ & 20.1 & 1.1 & $18-856.5$ & 46.5 & 95.9 & 68 & $18-856.5$ & 59.4 & 136.9 & 62 \\
\hline HCFC-141b & $18.5-23.5$ & 19.7 & 1.0 & $18.1-236.9$ & 30.2 & 21.3 & 68 & $18.1-101.9$ & 29.9 & 16.0 & 63 \\
\hline \multicolumn{12}{|l|}{ HFCs } \\
\hline HFC-134a & $43.1-54.0$ & 45.9 & 2.3 & $41.7-702$ & 87.8 & 67.3 & 81 & $41.7-702.0$ & 89.1 & 76.6 & 72 \\
\hline HFC-152a & $5.1-31.0$ & 8.9 & 5.0 & $4.7-398.3$ & 47.5 & 61.1 & 56 & $4.7-212.8$ & 42.5 & 40.3 & 60 \\
\hline \multicolumn{12}{|l|}{ Halons } \\
\hline H-1211 & $4.15-4.46$ & 4.26 & 0.06 & $4.14-6.45$ & 4.52 & 0.41 & 55 & $4.14-5.66$ & 4.50 & 0.32 & 58 \\
\hline H-2402 & $0.50-0.52$ & 0.51 & 0.01 & $0.48-0.53$ & 0.51 & 0.01 & $<1$ & 0.480 .53 & 0.51 & 0.01 & 14 \\
\hline H-1301 & $3.0-3.6$ & 3.3 & 0.1 & $2.9-4.3$ & 3.4 & 0.2 & 27 & 2.94 .3 & 3.4 & 0.2 & 27 \\
\hline \multicolumn{12}{|l|}{ Regulated Solvents } \\
\hline $\mathrm{CH}_{3} \mathrm{CCl}_{3}$ & $11.6-12.6$ & 12.2 & 0.2 & $11.8-17.9$ & 12.9 & 1.0 & 58 & $11.8-16.6$ & 13.0 & 1.1 & 56 \\
\hline $\mathrm{CCl}_{4}$ & $90.3-93.6$ & 91.9 & 0.8 & $90.8-94.8$ & 92.8 & 0.7 & 17 & $91.7-94.8$ & 92.8 & 0.6 & 14 \\
\hline \multicolumn{12}{|l|}{ Other Solvents } \\
\hline $\mathrm{CHCl}_{3}$ & $6.0-15.0$ & 9.2 & 1.9 & $6-56.0$ & 15.7 & 8.9 & 44 & $6.6-44.3$ & 15.5 & 8.3 & 46 \\
\hline $\mathrm{CH}_{2} \mathrm{Cl}_{2}$ & 22.9-61.9 & 36.3 & 8.7 & $24.5-318.6$ & 64.8 & 51.4 & 37 & $24.5-248.7$ & 62.4 & 38.4 & 47 \\
\hline $\mathrm{C}_{2} \mathrm{HCl}_{3}$ & $0.10-0.61$ & 0.23 & 0.08 & $0.08-24.5$ & 2.1 & 3.1 & 85 & $0.2-12.1$ & 1.8 & 1.9 & 72 \\
\hline $\mathrm{C}_{2} \mathrm{Cl}_{4}$ & $1.4-5.1$ & 2.9 & 1.0 & $1.36-156.3$ & 13.2 & 18.6 & 57 & $1.51-70.9$ & 11.9 & 11.6 & 61 \\
\hline
\end{tabular}

* number of samples with a mixing ratio $\geq$ mean of inflow air plus $2 \sigma$ (see text for explanation).

influence, but do not represent the regional background as they could be affected by polluted air masses intercepted over the Pacific Ocean. Instead, the ocean air samples characterize the inflow towards California before being impacted by fresh pollution plumes generated within North America.

As expected, the average mixing ratios for the majority of the halogenated compounds in the inflow air were lower than the average levels measured over the LA area and So$\mathrm{CAB}$. Additionally, the variation in the halocarbon levels was much lower in the inflow samples compared to samples obtained over the mainland (Table 2), which is consistent with the presence of significant land-based emission sources. The fraction of samples collected in the LA area and SoCAB that contained halocarbon mixing ratios higher than the inflow samples was determined by calculating the number of samples with levels exceeding the average inflow mixing ratio plus two standard deviations $(2 \sigma)$. This high-reference level (average inflow plus $2 \sigma$ ) was set to avoid overestimating the halocarbon enhancement in the LA area and SoCAB.
For the CFCs and their replacements, with the exception of CFC-113 (1,1,2-trichloro-1,2,2-trifluoroethane, $\mathrm{C}_{2} \mathrm{Cl}_{3} \mathrm{~F}_{3}$ ) and $\mathrm{CFC}-114$, concentrations exceeding the reference level were observed in a majority $(60-80 \%)$ of air samples obtained over the LA area and SoCAB (Table 2 and Fig. 3). The CFC-114 mixing ratios measured in these regions were similar to the inflow air masses, with $\sim 30 \%$ of the samples showing enhanced levels. Reduced enhancements also were observed for CFC-113 over the SoCAB (37\% of samples with enhanced mixing ratios) but not over the LA area $(60 \%$ of samples with enhanced mixing ratios). A relatively small fraction of samples with enhanced mixing ratios were observed for halon-2402 (dibromotetrafluoroethane, $\mathrm{C}_{2} \mathrm{Br}_{2} \mathrm{~F}_{4}$; $14 \%$ and $<1 \%$ in the LA area and the SoCAB, respectively), halon-1301 (Bromotrifluoromethane, $\mathrm{CBrF}_{3} ; 27 \%$ in both regions; Fig. $4 \mathrm{a})$, and $\mathrm{CCl}_{4}$ (14\% and $17 \%$ in the $\mathrm{LA}$ area and SoCAB, respectively). However, halon-1211 and $\mathrm{CH}_{3} \mathrm{CCl}_{3}$ levels were elevated in a majority of the collected samples $(\sim 55 \%$; Fig. $4 \mathrm{~b}$ and c). 

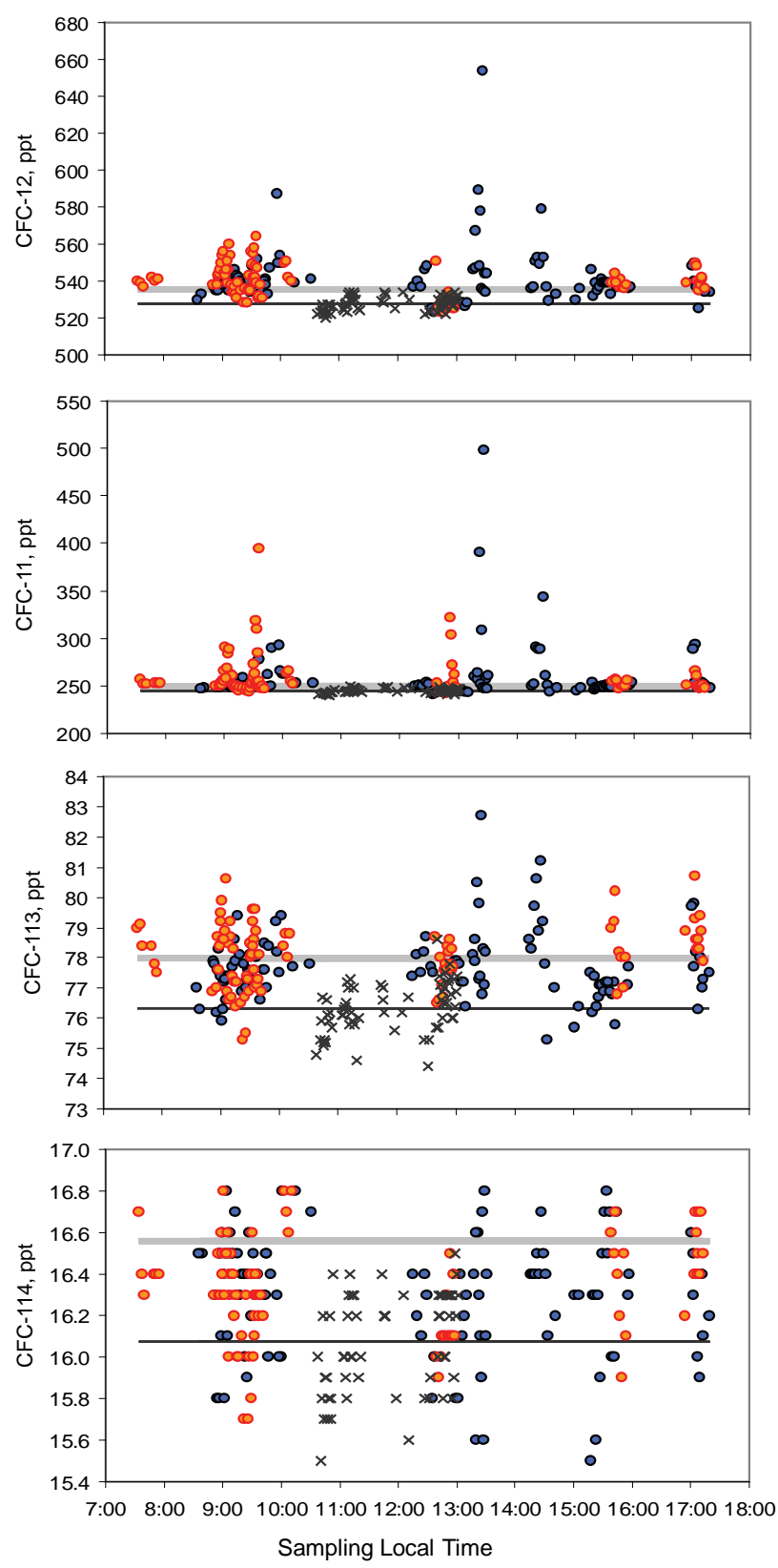

Fig. 3. Mixing ratio of CFCs in samples collected over the LA area (orange filled circles), the remaining SoCAB (blue filled circles), and offshore in the inflow air masses (black crosses). The black line indicates the average of the inflow, while the grey line represents the average plus two standard deviations.

Although previous studies reported ongoing emissions of regulated CFCs and other halogenated compounds in North America (Hurst et al., 2006; Barletta et al., 2009; Millet et al., 2009), the consistently enhanced levels measured during the ARCTAS-CARB flights allow a closer identification of one possible source region (i.e., California) and show the presence of such sources during the summer of 2008 .
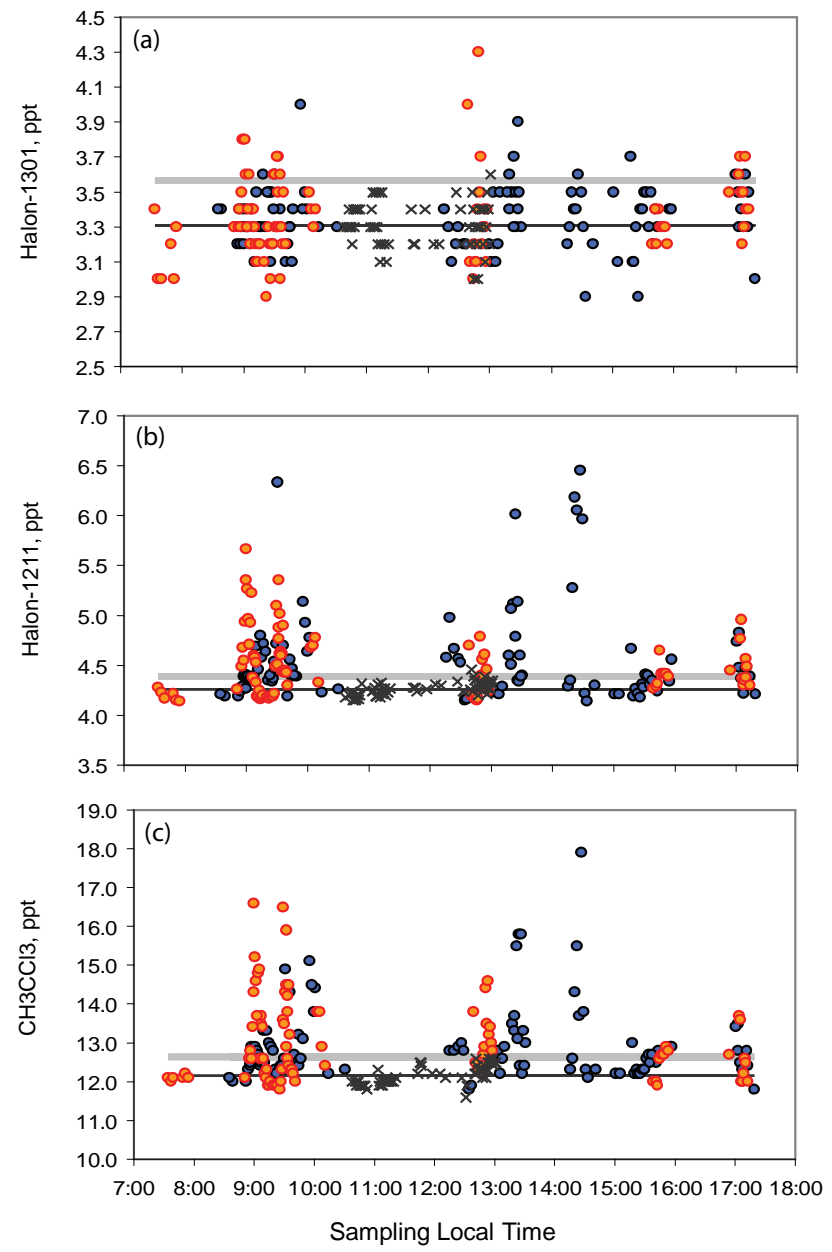

Fig. 4. Mixing ratio of (a) Halon-1301, (b) Halon-1211, (c) $\mathrm{CH}_{3} \mathrm{CCl}_{3}$ in samples collected over the LA area (orange filled circles), the remaining SoCAB (blue filled circles), and offshore in the inflow air masses (black crosses). The black line indicates the average of the inflow, while the grey line represents the average plus two standard deviations.

Among the 196 air samples obtained over the SoCAB during the ARCTAS-CARB study a small fraction collected during Flight 12 contained exceptionally high levels of halocarbons (Fig. 5). Three consecutive samples collected during 13:2213:26 (local time) at an altitude of $0.3 \mathrm{~km}$ over the northern area of the Orange County (near +33.8 latitude $N,-118.0$ longitude $\mathrm{W}$ ) and five consecutive samples collected during 14:20-14:29 (local time) at an altitude of $0.6-1.0 \mathrm{~km}$ over a southwest to northeast leg across the SoCAB contained the highest levels of many halogenated compounds observed during the study. The wind speed range recorded on the DC- 8 for these samples was $1-7 \mathrm{~m} \mathrm{~s}^{-1}$ with winds coming from the west for the first set of three samples and from the west-southwest for the remaining five samples. For example, $\mathrm{C}_{2} \mathrm{Cl}_{4}$ mixing ratios were $75-90 \mathrm{ppt}$ in the first set of three samples and 35-156 ppt in the second set of five samples 


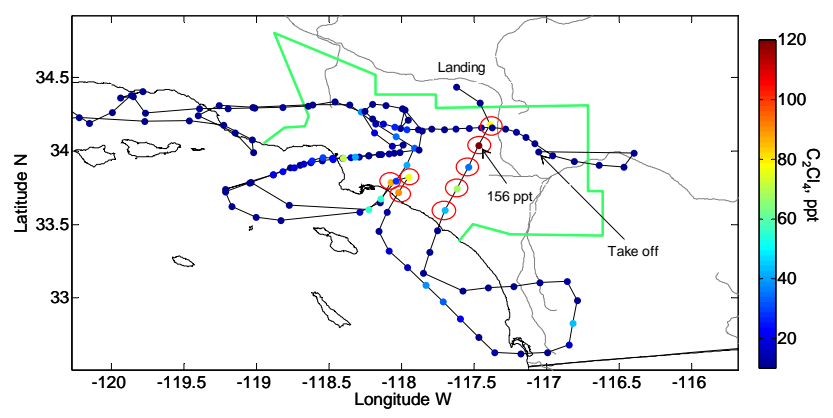

Fig. 5. Geographic distribution of samples collected during Flight 12 , color-coded by $\mathrm{C}_{2} \mathrm{Cl}_{4}$ mixing ratios (the line connecting the samples illustrates the flight path). The samples circled in red correspond to canisters showing greatly enhanced halocarbon levels.

compared to $2.9 \pm 1.0 \mathrm{ppt}$ in the inflow (Fig. 5). The sources responsible for these high emissions are not known, but the locations of these exceptionally high halocarbon mixing ratios are presented here as they may be important sites for future studies.

\subsection{Regional emission rate estimates for HFC-152a and HFC-134a}

Figure 6 shows the mixing ratios of HFC-152a and HFC134a measured in the SoCAB during the ARCTAS-CARB study (HFC-152a and HFC-134a mixing ratios measured for all the ARCTAS-CARB samples are reported in Supplement Fig. 1). Concentrations of both HFCs over the mainland were much higher than in the inflow air mass, indicating the presence of significant emission sources of HFC-152a and HFC-134a in the LA area and SoCAB. HFC-152a was enhanced by a factor of five over the mainland $(48 \pm 61 \mathrm{ppt}$ and $43 \pm 40 \mathrm{ppt}$ in the LA area and SoCAB, respectively) compared to the inflow $(9 \pm 5 \mathrm{ppt})$ (Table 2). The HFC152a inflow level calculated in our study is in excellent agreement with the AGAGE (Advanced Global Atmospheric Gases Experiment) measurements at Trinidad Head, California $(8.7 \pm 0.5 \mathrm{ppt}$ measured by the GC-MS Medusa instrument in June 2008; AGAGE, 2010). Approximately $12 \%$ of the samples collected over the LA area and the remaining SoCAB had a mixing ratio higher than $100 \mathrm{ppt}$, representing about 10 times the mean levels in the inflow air masses. The highest measured mixing ratios were 213,133 , and $127 \mathrm{ppt}$ over the LA area and 370,279, and 303 ppt for the remaining SoCAB. For HFC-134a, the average mixing ratio over the LA area $(89 \pm 77 \mathrm{ppt})$ and SoCAB $(88 \pm 67 \mathrm{ppt})$ was approximately twice the average mixing ratio measured in the inflow (46 $\pm 2 \mathrm{ppt}$ ), with a lower absolute enhancement compared to HFC-152a. The number of samples with a mixing ratio higher than $100 \mathrm{ppt}$ (about double the levels in the inflow) over the LA area and the remaining SoCAB were $29 \%$ and $23 \%$, respectively.
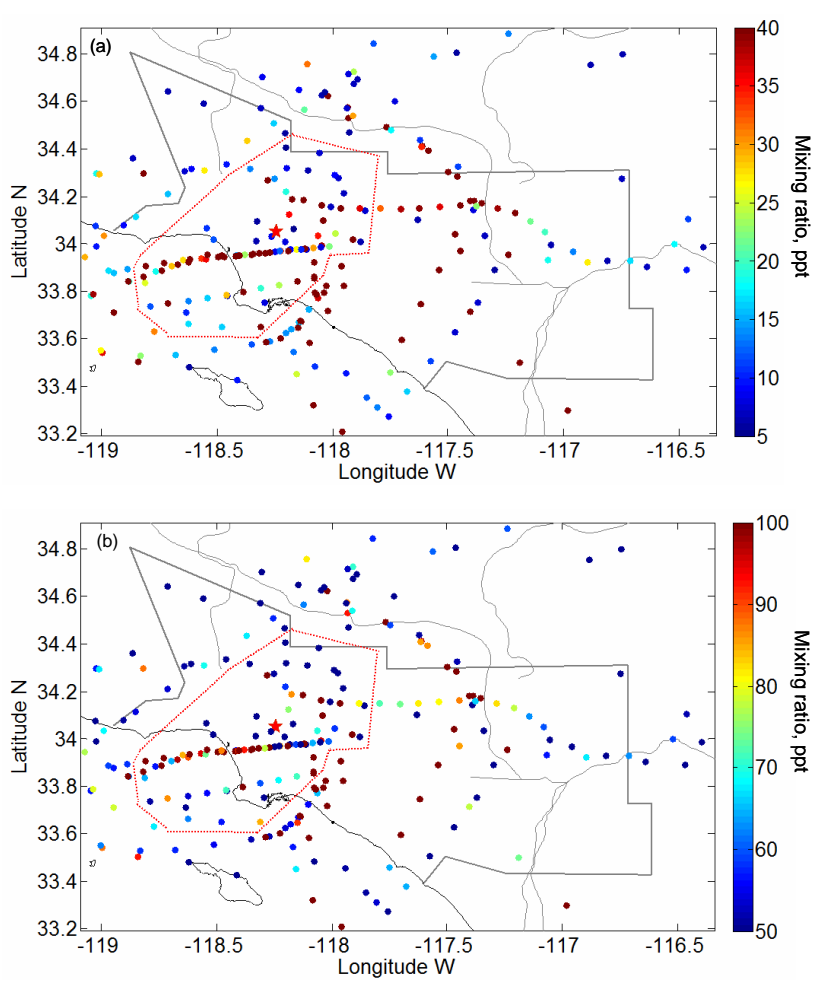

Fig. 6. Mixing ratios (ppt) of (a) HFC-152a and (b) HFC-134a measured over the SoCAB (boundary indicated by the solid gray line). The samples included within the red dotted line are the data points used to calculate emissions from the LA County. Downtown Los Angeles is indicated by the red star.

There is considerable spatial variability of HFC concentrations across the SoCAB. However, elevated levels of both HFC-152a and HFC-134a often are observed simultaneously (coefficient of determination of 0.84 in the SoCAB). Therefore, the spatial variability likely is not due to localized point sources since emissions by point sources would selectively enhance only one species. Instead, the presence of stagnant air around the sampling area may be the cause of the observed build-up in trace gases. Air stagnation events in the US are most prevalent in the southern states and during the summertime when the winds are weaker (Wang and Angell, 1999). The wind speed was $4 \pm 3 \mathrm{~m} \mathrm{~s}^{-1}$ during the time the LA area samples were collected.

It is possible to gain insight into the degree of stagnation and atmospheric processing of an air mass by examining the ratio of hydrocarbon species with common emission sources but different atmospheric lifetimes (Parrish et al., 2007 and references therein). The ethyne: $\mathrm{CO}$ ratio is of particular interest because combustion is the main emission source for both species and their removal from the troposphere is controlled primarily by reaction with hydroxyl radicals $(\mathrm{OH})$, with a faster removal rate for ethyne (lifetime of about 23 weeks; Xiao et al., 2007) than CO (lifetime of about two 
months; Logan et al., 1981). Typically, these two trace gases are strongly correlated and the ethyne: $\mathrm{CO}$ ratio decreases with time due to the faster removal rate of ethyne. A ratio of about $9 \mathrm{ppt} \mathrm{ppb}^{-1}$ has been observed for air masses less than one day old (Talbot et al., 2003), while lower ratios have

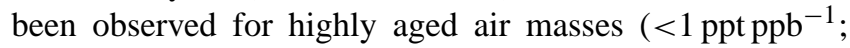
Barletta et al., 2009). The SoCAB is a coastal area receiving highly aged air masses from Asia due to the long transport time required to cross the Pacific Ocean. The average ethyne: $\mathrm{CO}$ ratio in the 60 inflow air samples was quite low, $0.8 \pm 0.5 \mathrm{ppt} \mathrm{ppb}^{-1}$. In order to examine the ethyne:CO ratio in samples that have been influenced by emissions from the SoCAB, only samples with $\mathrm{CO}$ levels higher than the average mixing ratio measured for the inflow samples (100 ppb) are selected for analysis. After removing samples with [CO] $<100 \mathrm{ppb}$, the average ethyne:CO ratio in the SoCAB samples was $2.2 \pm 1.2 \mathrm{ppt} \mathrm{ppb}^{-1}$, suggesting that the air masses investigated in our study were subject to atmospheric processing before being sampled. Therefore, it is possible that pollutants, such as HFC-152a and HFC-134a, can accumulate in areas due to variable wind patterns.

The main uses of HFC-152a and HFC-134a support the idea that emissions are spread more evenly across the SoCAB. HFC-152a is used widely as an aerosol propellant in many commercial products. Mobile air-conditioner (MAC) systems are the largest and most emissive sales market for HFC-134a (Papasavva et al., 2009). The HFC-134a leakage rate from MAC systems increases during the summer when MAC units are used more frequently. Significant amounts of the refrigerant can be lost during a vehicle's lifetime; Wimberger (2010) took HFC-134a samples from vehicles on dismantler lots in California and found that on average only $27 \%$ of the initial HFC-134a remained in the MAC system before dismantlement.

\subsubsection{Emission rate estimates from the "tracer ratio" method}

The first method of obtaining emission rate estimates of HFC-152a and HFC-134a uses the HFC:CO concentration ratio obtained from field measurements in the LA area (the red area in Fig. 2). The measured volume ratios were converted into mass ratios and multiplied by the $2008 \mathrm{CO}$ emission rate in LA County, providing an estimate of HFC152a and HFC-134a emissions in LA County for 2008. The ARCTAS-CARB flights flew over part of LA County and it is assumed that the HFC:CO slope for the LA area (land area $\left.\sim 3700 \mathrm{~km}^{2}\right)$ is the same as the HFC:CO slope that would be observed over LA County $\left(\sim 10518 \mathrm{~km}^{2}\right)$.

This method has been used extensively in previous studies to estimate emissions of several species (e.g., Reimann et al., 2005; Yokouchi et al., 2006; Greally et al., 2007; Millet et al., 2009). The validity of the tracer ratio method relies on three main assumptions: (1) the HFC and CO sources are co-located, (2) the emission rate of one of the two species is well-known (CO in this case), and (3) the chemical compounds have a lifetime longer than the typical transport time, which is true for CO (lifetime $\sim$ two months), HFC-152a ( $\sim 1.5 \mathrm{yr})$, and HFC-134a ( $\sim 14 \mathrm{yr})$ (Forster et al., 2007). Figures 7 and 8 show the strong correlation of HFC-152a and HFC-134a with CO for the samples collected in the LA area. Statistical outliers ( $>0.98$ percentile) and data points with a $\mathrm{CO}$ mixing ratio below $100 \mathrm{ppb}$ were excluded as they likely are from air masses not affected by anthropogenic emissions. Although different emission sources probably are responsible for the emission of $\mathrm{CO}$ and the two HFCs, the co-location of CO and HFC sources within the LA area results in the good correlation observed between these species (coefficient of determination $R^{2}=0.85$ for HFC-152a vs. $\mathrm{CO}$ and $R^{2}=0.67$ for HFC-134a vs. CO). The slope of the orthogonal distance regression line through the data points represents the HFC:CO molar ratio. A ratio of $0.59 \pm 0.06$ $\mathrm{mmol} \mathrm{mol}^{-1}$ and $0.59 \pm 0.10 \mathrm{mmol} \mathrm{mol}^{-1}$ were observed for HFC-152a:CO and HFC-134a:CO, respectively. These volume ratios were multiplied by molecular weights to convert them into mass ratios, and then multiplied by the 2008 $\mathrm{CO}$ emission rate in LA County $\left(1.8 \times 10^{9} \mathrm{~g} \mathrm{day}^{-1}\right.$; CARB, 2008) to obtain HFC emissions from the LA County.

Using the tracer ratio method, the emissions of HFC-152a and HFC-134a in 2008 are estimated to be $0.90 \pm 0.09 \mathrm{Gg}$ and $1.39 \pm 0.24 \mathrm{Gg}$, respectively. However, these annual emission rates must be adjusted to account for seasonal variability since the emission rates of the two HFCs are higher during the summer. Using an approach similar to Millet et al. (2009), seasonality correction factors are computed using halocarbon: $\mathrm{CO}$ ratios observed during a three year period (1996-1998) in the Northeastern US (Barnes et al., 2003). However, the seasonal variability in HFC emission rates in the Northeastern US likely is more pronounced than in the Southwestern US where inter-seasonal temperature differences are less extreme. The seasonality correction factors are adapted to Southern California using the findings from Papasavva et al. (2009). In that study, leakage rates of a potential alternative for HFC-134a in MAC systems, HFC1234yf (2,3,3,3-tetrafluoropropene), are estimated for individual states. In light of the data from Barnes et al. (2003) and Papasavva et al. (2009), the season-adjusted emission estimates for LA County in 2008 are $0.82 \pm 0.11 \mathrm{Gg}$ and $1.16 \pm 0.22 \mathrm{Gg}$ for HFC-152a and HFC-134a, respectively (see Supplement for details about the seasonal scaling factors). The uncertainty in the HFC emissions only reflects the error in the slope (95\% confidence level) calculated from the orthogonal regression between the individual HFC and $\mathrm{CO}$ mixing ratios and the uncertainty in the seasonal scaling factors. The total CO emitted by LA County in 2008 is another potential source of error and should be considered when calculating the uncertainty in emissions estimates. Unfortunately, the uncertainty in $\mathrm{CO}$ emissions has not been determined by CARB and cannot be included in the analysis. 


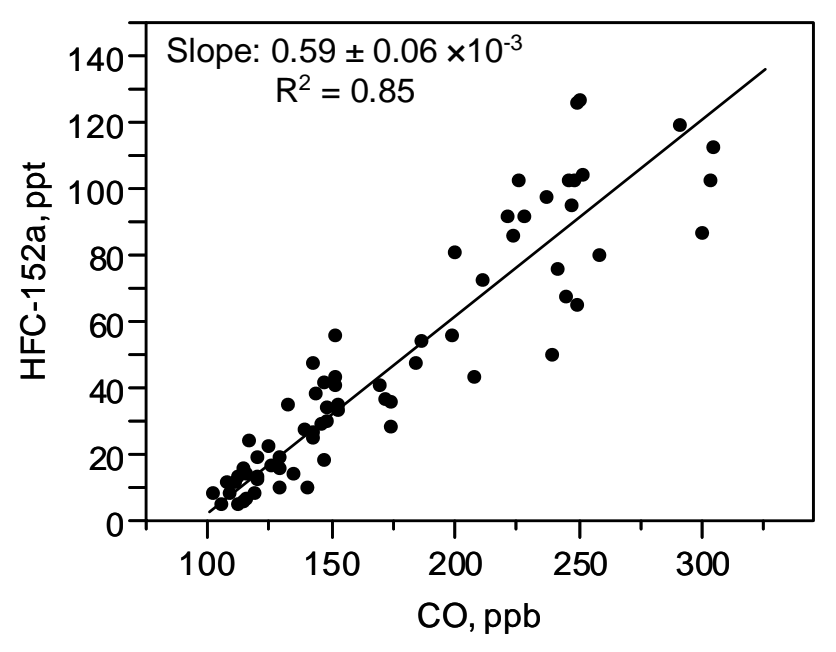

Fig. 7. Mixing ratios of HFC-152a versus CO for the samples collected over the LA area.

The tracer ratio method also is employed to estimate HFC emissions from the SoCAB using the measurements collected within the SoCAB and the $2008 \mathrm{CO}$ emission rate in the SoCAB $\left(3.1 \times 10^{9} \mathrm{~g} \mathrm{day}^{-1}\right.$; CARB, 2008). Values of $0.66 \pm 0.07 \mathrm{mmol} \mathrm{mol}^{-1}$ and $0.58 \pm 0.06 \mathrm{mmol} \mathrm{mol}^{-1}$ are observed for the HFC-152a:CO and HFC-134a:CO ratios, respectively (coefficient of determination $R^{2}=0.71$ for HFC$152 \mathrm{a}$ vs. $\mathrm{CO}$ and $R^{2}=0.67$ for HFC-134a vs. CO. Plots are available in Supplement Fig. 2). The HFC emissions calculated for the SoCAB are adjusted to account for seasonal variability using the same scaling factors applied to the LA County emissions. The season-adjusted emission estimates for the SoCAB in 2008 are $1.60 \pm 0.22 \mathrm{Gg}$ for HFC-152a and $2.12 \pm 0.28 \mathrm{Gg}$ for HFC-134a. The uncertainty in the HFC emissions reflects the error in the slope calculated from the orthogonal regression between the individual HFC and $\mathrm{CO}$ mixing ratios and the uncertainty in the seasonal scaling factors, but not the error in the $2008 \mathrm{CO}$ emissions from the SoCAB as these data are not available from CARB.

Estimates for HFC-152a and HFC-134a emissions in the US are obtained by using population data to extrapolate the emissions estimates from SoCAB. This method assumes that the HFC emissions in the US are proportional to population, an approach used in previous studies (e.g., Millet and Goldstein, 2004; Li et al., 2005; Stohl et al., 2009). Stohl et al. (2009) states that global emissions estimates calculated using population data likely overpredict emissions from developing countries, but this error is reduced when the use of the population data is confined to a single nation. The reliability of the population-based method is evaluated by comparing HFC emissions estimates for the So$\mathrm{CAB}$ obtained using (1) the tracer ratio method and through (2) extrapolation of the LA County estimates to the SoCAB using population data from the United States Census Bu-

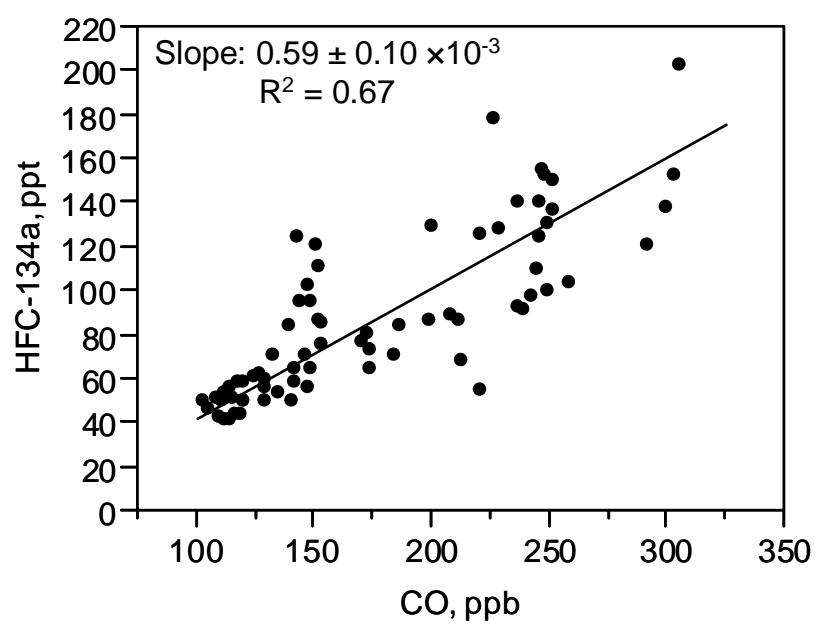

Fig. 8. Mixing ratios of HFC-134a versus CO for the samples collected over the LA area.

reau (USCensus, 2009) and South Coast Air Quality Management District (SCAQMD, 2008). The estimates derived from the population-based method $\left(1.25 \pm 0.16 \mathrm{Gg} \mathrm{yr}^{-1}\right.$ and $1.77 \pm 0.34 \mathrm{Gg} \mathrm{yr}^{-1}$ for HFC-152a and HFC-134a, respectively) are within the stated uncertainties of the estimates obtained using the tracer ratio method $\left(1.60 \pm 0.22 \mathrm{Gg} \mathrm{yr}^{-1}\right.$ and $2.12 \pm 0.28 \mathrm{Gg} \mathrm{yr}^{-1}$ for HFC-152a and HFC-134a, respectively), although this good agreement likely is due in part to the similar weather and demographics of LA County and the SoCAB.

Using additional population data from the US Census $\mathrm{Bu}-$ reau (USCensus, 2011), this study estimates that the US emitted $32 \pm 4 \mathrm{Gg}$ of HFC-152a and $43 \pm 6 \mathrm{Gg}$ of HFC134a in 2008. The uncertainty accounts for the error in the HFC:CO slope for the SoCAB samples and the error in the seasonal variability correction factor. Regional effects (warmer climates having greater leakage rates than colder climates due to higher temperatures and more frequent MAC usage) also may need to be considered, but are difficult to estimate. Papasavva et al. (2009) predicts that the leakage rate (gram per vehicle) of MAC refrigerants from cars in California will be about $4 \%$ higher than the national average in 2017. This result suggests that regional effects may not affect estimates of HFC-134a emissions significantly.

Previous studies calculate lower HFC-152a emission rates for the US. Stohl et al. (2009) estimated that US emissions of HFC-152a in 2005 and 2006 were $10.1 \mathrm{Gg}$ and $12.5 \mathrm{Gg}$, respectively ( $\sim 24 \%$ increase between the two years). If the US maintained this high annual increase through 2008, Stohl et al.'s data yields $19 \mathrm{Gg}$ in $2008,40 \%$ below the estimate in the present study. An even lower estimate is reported by Millet et al. (2009), with 5.7-9.7 Gg in 2006. The reasons for the discrepancy between the HFC-152a emissions estimates from previous studies and the current study is not known, but it is possible that the specific source regions investigated in 
one or more of the studies are not representative of the overall emissions in the US. It also is possible that seasonal and regional variations play a role in the discrepancies between this study and other estimates. The methodology utilized by Millet et al. (2009) was similar to the tracer ratio method, but they used measurements from the TEXAQS-II study over Southern Texas during September-October 2006. Additionally, Millet et al. (2009) extrapolated HFC-152a emissions to the entire US using national CO emission data, not population data like the present study. Stohl et al. (2009) used a completely different methodology (global backward trajectory modeling) and field measurements from nine locations across the world in deriving their estimate.

It should be noted that the United States generally is regarded as the "largest user" of HFC-152a (Ashford et al., 2004). Although much of the future growth in HFC-152a use is expected to come from East Asia, Stohl et al. (2010) estimate that the contribution of that region to the global HFC152a emissions was only about $10 \%$ ( $\sim 7 \%$ from China) in 2008. Greally et al. (2007) estimated that global HFC-152a emissions increased at an average rate of $\sim 14 \%$ per year during 1994-2004, reaching $28 \pm 4 \mathrm{Gg}$ in 2004. If global HFC152a emissions continued to increase at the same annual rate through 2008, Greally et al.'s data yields global emissions of $36 \mathrm{Gg}$ in 2006 and $47 \mathrm{Gg}$ in 2008. The extrapolated emission estimate for 2006 agrees well with the global emission estimate of $37 \mathrm{Gg} \mathrm{yr}^{-1}$ obtained by Stohl et al. (2009) for the years 2005-2006. The US emissions estimate of HFC-152a from this study ( $32 \mathrm{Gg}$ in 2008) is consistent with the US being the world's largest user of HFC-152a. Conversely, the US emission rate estimates from Stohl et al. (2009) and Millet et al. (2009) are less than $50 \%$ of the total global emissions calculated by Greally et al. (2007) and Stohl et al. (2009).

The HFC-134a emissions estimates for US derived in this study (43 Gg in 2008) generally agree well with other studies. Manning and Weiss (2007) estimate the US emitted $43 \mathrm{Gg}$ (22-60 Gg range) in 2006. In that study, HFC-134a emissions for the western US were determined by running backward simulations of a Lagrangian atmospheric dispersion model and using ground-based observations at the AGAGE measurement station at Trinidad Head on the Northern California coast. The emission rate for the western US was extrapolated to the entire US using population data. Stohl et al. (2009) report US emissions of $35 \mathrm{Gg}$ in 2005, while Millet et al. (2009) report emissions of $12-39 \mathrm{Gg} \mathrm{yr}^{-1}$ during 2004-2006. Keeping in mind the present study estimates emissions from 2008 and that the demand in HFCs in the US is projected to increase by about $7 \%$ per year from 2008 to 2020 (Velders et al., 2009), all of these studies agree with each other within the margin of error.

\subsubsection{Emission rate estimates from the "AQM" method}

This study utilizes a second method to obtain emissions estimates of HFC-152a and HFC-134a in LA County and the
SoCAB during 2008 using an air quality model to reproduce field measurements obtained during ARCTAS-CARB flights. In the model it is assumed that HFC-152a and HFC-134a are emitted at a constant rate from urban areas across the So$\mathrm{CAB}$. The emission rates are incrementally adjusted until the average mixing ratio from the simulations matches the average mixing ratio from field measurements.

Air quality simulations were performed using the UCICIT Air Quality Model, a three-dimensional Eulerian urban photochemical model designed to study the dynamics of pollutant transformation and transport in the SoCAB of California (Griffin et al., 2002a, b). The UCI-CIT model uses a horizontal $80 \times 30$ rectangular grid with five vertical layers, the highest layer extending to $1100 \mathrm{~m}$. Each grid cell corresponds to a $5 \mathrm{~km} \times 5 \mathrm{~km}$ region.

The predicted concentrations of HFC-152a and HFC-134a were determined primarily by the emission rates and meteorology. Although these two HFC species react with $\mathrm{OH}$, loss due to chemical reaction and deposition is insignificant compared to loss from transport (Forster et al., 2007). Since a complete meteorological data set was not available for the June 2008 field campaign, multiple simulations were conducted using meteorological data sets from field campaigns that occurred in the SoCAB during August 27-28, 1987 (Meng et al., 1998), 8-9 September 1993 (Griffin et al., 2002b), and 18-19 October 1995 (Knipping and Dabdub, 2002). The wind patterns during the August 1987, September 1993, October 1995, and June 2008 field campaigns are similar - relatively calm winds during the night and early morning and steady on-shore winds midday. A comparison of wind speed and direction at three locations in the SoCAB is provided in Supplement Table 1. Conducting simulations using six different meteorological data sets created a range of predicted HFC-152a and HFC-134a mixing ratios that were compared to field measurements. The emission rate in the model was incrementally adjusted until the average mixing ratios from the six simulations matched the average mixing ratio measured during the ARCTAS-CARB flights in the LA area and SoCAB.

The UCI-CIT model spins up for five simulation days allowing the system to reach a steady diurnal cycle. The data presented here are from the last simulation day. In the simulations, it is assumed that HFC-152a and HFC-134a are emitted evenly across all urban cells at a constant rate every hour, while emissions from rural cells are zero. Separate sets of simulations were conducted to determine the emission rates in the LA area and SoCAB. As in the tracer method, simulation results from the LA area were extrapolated to LA County. The inflow concentrations for HFC-152a (9 pptv) and HFC-134a (46 pptv) were obtained from field measurements over the Pacific Ocean. As winds blow across the domain, "clean" air (at inflow concentrations) enters the domain while "polluted" air (at elevated concentrations due to emissions and transport) is removed downwind. During most of the simulations, clean air enters from the western edge of 
the domain and polluted air leaves through the eastern edge of the domain.

In the simulations, the average hourly concentration of each species was calculated at each cell and vertical layer - for both HFCs, the concentration at $80 \times 30 \times 5$ locations was calculated every hour. In order to find the average mixing ratio of species $i$ in a cell $k$ at hour $h\left(\bar{c}_{h, i, k}\right)$ the weighted average of all five vertical layers was calculated, accounting for differences in air pressure and layer thickness (the details of how $\bar{c}_{h, i, k}$ is calculated are included in the Supplement). The average concentration of species $i$ across the LA area or SoCAB at a given hour was calculated by averaging $\bar{c}_{h, i, k}$ over all cells in the area of interest,

$\bar{c}_{h, i, \text { area }}=\frac{1}{N_{\mathrm{c}}} \sum_{k=1}^{N_{\mathrm{c}}} \bar{c}_{h, i, k}$,

where $N_{\mathrm{c}}$ is the total number of cells comprising the region of interest and the subscript area is either LAA or SoCAB.

In the simulations, the diurnal profile of HFC-152a and HFC-134a varies with elevation. For each hour the average concentration of species $i$ across the LA area or SoCAB at a vertical layer $j$ is,

$\bar{c}_{h, i, j}=\frac{1}{N_{\mathrm{c}}} \sum_{k=1}^{N_{\mathrm{c}}} c_{h, i, j, k}$.

Figure 9 shows the average concentration and 1- $\sigma$ values of HFC-152a in the cells comprising the SoCAB for each layer (Fig. 9a-e) and the weighted average of all five layers (Fig. 9f) using the 9 September 1993 meteorological data set (see Supplement Fig. 3 for plots of HFC-134a in the SoCAB, and Supplement Figs. 4 and 5 for plots of HFC-152a and HFC-134a in the LA area). Similar results were obtained using the other five meteorological data sets. Model predictions were compared to field measurements from the ARCTASCARB flights, which are shown as black dots in Fig. 9.

At the lowest layer in the UCI-CIT model (0-38.5 m) the average concentration in the LA area and SoCAB was relatively high in the morning but decreased during the day as onshore winds increased and relatively clean ocean air blew into the region, pushing HFC-152a and HFC-134a eastward out of the SoCAB. In the late afternoon and evening the wind speed decreased, resulting in an accumulation of the HFCs. A similar trend was seen in the second layer $(38.5-154 \mathrm{~m})$. In the upper three layers of the model (layer 3 $=154-308 \mathrm{~m}$; layer $4=308-671 \mathrm{~m}$; layer $5=671-1100 \mathrm{~m}$ ), vertical mixing transports the HFCs upward from the lower layers as the winds increased midday, resulting in elevated mixing ratios in the upper layers at that time. It should be noted that although the mixing ratio was highest at the ground layer and generally decreased with altitude, the overall diurnal pattern in a cell (averaging over all five layers) was determined primarily by the mixing ratio in the upper layers since those layers are significantly taller than the lower layers.
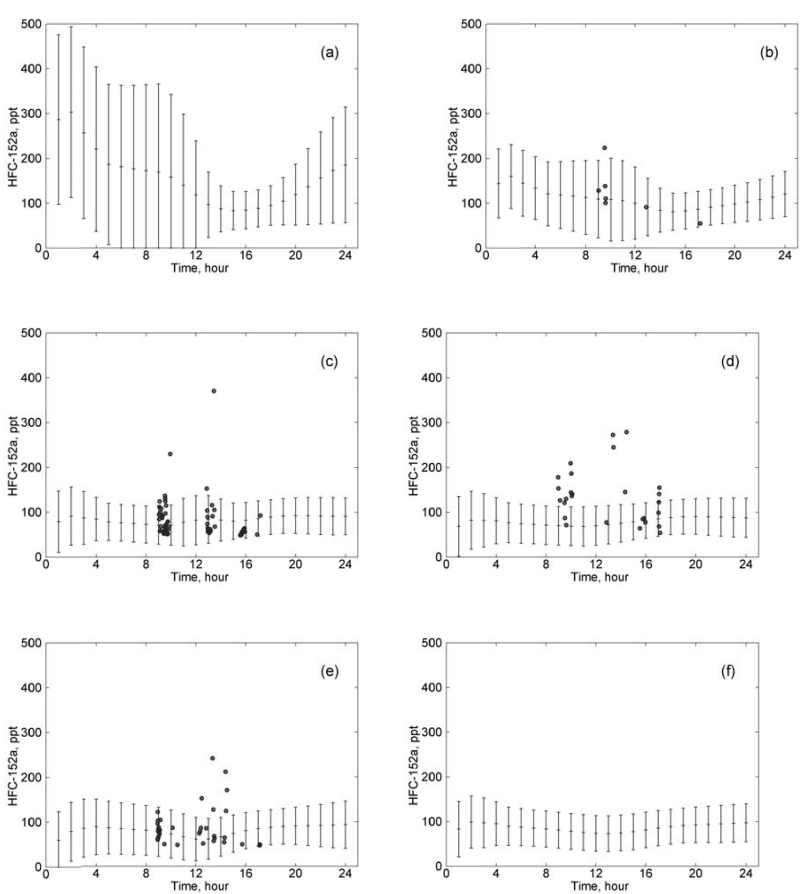

Fig. 9. The mean concentration and $1-\sigma$ values of HFC-152a at different vertical layers in the cells comprising the SoCAB, as calculated by the UCI-CIT model using the 9 September 1993 meteorological data set and land-use data from the USGS. The mean concentration in the (a) lowest layer, (b) second layer, (c) third layer, (d) fourth layer, and (e) highest layer are calculated using Eq. (4) in the Supplement. The average concentration over all vertical layers in the SoCAB (f) is calculated using Eq. (3) in the Supplement. Measurements from the ARCTAS-CARB flights are shown as solid black dots. No measurements were collected in the lowest layer.

Figure 9 demonstrates that the UCI-CIT model was able to reproduce measurements from the ARCTAS-CARB flights well qualitatively - most measurements fall within a factor of two of the mean predictions. In order to compare the results from the UCI-CIT model to field measurements quantitatively, the average predicted concentration in the LA area and SoCAB during 08:00 a.m.-06:00 p.m. was determined by averaging the values of $\bar{c}_{h, i, \mathrm{LAA}}$ from $h=8$ to $h=17$, the time range in which the field measurements were collected,

$\hat{c}_{i, \text { area }}=\frac{1}{10 \mathrm{~h}} \sum_{h=8}^{17} \bar{c}_{h, i, \mathrm{LAA}}$.

The average measured mixing ratios in the LA area and SoCAB were determined in a similar manner as $\hat{c}_{i, \text { area }}$ in Eq. (3). Air samples collected at altitudes between $0 \mathrm{~m}$ and $1100 \mathrm{~m}$ during the ARCTAS-CARB flights were sorted by elevation into five bins that are the same height as the layers in the UCI-CIT model. The average concentration in each bin was calculated and the total mixing ratio from $0 \mathrm{~m}$ to $1100 \mathrm{~m}$ was determined by taking a weighted average of all five layers, accounting for differences in air pressure and layer size. 
Table 3. Average measured and predicted mixing ratios (in ppt) of HFC-152a and HFC-134a in the LA area and SoCAB (0-1100 $\mathrm{m}$ in elevation) during 08:00 a.m.-06:00 p.m.

\begin{tabular}{lcccc}
\hline & \multicolumn{2}{c}{ LA area* } & \multicolumn{2}{c}{ SoCAB* } \\
Meteorology & [HFC-152a] & [HFC-134a] & [HFC-152a] & [HFC-134a] \\
\hline Aug 27, 1987 & 42 & 79 & 68 & 99 \\
Aug 28, 1987 & 49 & 92 & 62 & 95 \\
Sep 8, 1993 & 64 & 111 & 99 & 130 \\
Sep 9, 1993 & 57 & 99 & 91 & 119 \\
Oct 18, 1995 & 53 & 91 & 69 & 131 \\
Oct 19, 1995 & 73 & 124 & 60 & 91 \\
Average of six simulations & 57 & 100 & 75 & 111 \\
Average of field measurements & 57 & 100 & 75 & 111 \\
\hline
\end{tabular}

* Landuse data from the United States Geological Survey. The fraction of urban cells in the LA area and SoCAB is $76 \%$ and $49 \%$, respectively.

Table 3 lists the average measured and predicted mixing ratios of HFC-152a and HFC-134a in the LA area and SoCAB during 08:00 a.m.-06:00 p.m. Six different meteorological data sets were used in the UCI-CIT model. Although the value of $\hat{c}_{i, \text { area }}$ is dependent upon meteorology, Table 3 shows that model predictions of the average concentration of HFC-152a and HFC-134a in the LA area and SoCAB for all six meteorological data sets vary less than $35 \%$ from the mean value.

The emission rate estimates were determined by incrementally adjusting the emission rate from urban cells in the model until the average $\hat{c}_{i \text {,area }}$ from all six simulations was the same as the average mixing ratio in the LA area and SoCAB determined from field measurements. The urban emission rates for these two regions, $E_{\text {urban,LAA }}$ and $E_{\text {urban,SoCAB }}$, were multiplied by the fraction of urban cells in those regions to obtain the average emission rate in the LA area and SoCAB,

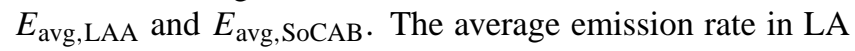
County, $E_{\text {avg,LAC, }}$ was calculated by multiplying $E_{\text {avg,LAA }}$ by the ratio of land area in LA County to the land area in the LA area $\left(10518 \mathrm{~km}^{2} / 3700 \mathrm{~km}^{2}\right)$. The UCI-CIT model uses landuse data collected during the 1970s by the United States Geological Survey (USGS). Based on this data, the fraction of urban cells in the LA area and SoCAB is $76 \%$ and $49 \%$, respectively. However, there has been considerable urban sprawl in the SoCAB since the 1970s. An alternate scenario was examined in which $100 \%$ of the cells in the SoCAB are classified as urban (all cells in the SoCAB emit at the same rate). The actual fraction of urban cells in the LA area and SoCAB is between $100 \%$ and the fraction provided by the USGS.

Emission rates for LA County and the SoCAB from the AQM method agree well with estimates from the tracer ratio method described in the previous section (Table 4). Using land-use data from the 1970 s to determine which cells are classified as urban, the UCI-CIT model predicts LA County 2008 emissions of $0.72 \pm 0.14 \mathrm{Gg}$ and $1.26 \pm 0.20 \mathrm{Gg}$ for HFC-152a and HFC-134a, respec- tively. For the SoCAB, the model predicts emissions of $0.91 \pm 0.20 \mathrm{Gg}$ and $1.29 \pm 0.21 \mathrm{Gg}$ for HFC-152a and HFC$134 \mathrm{a}$, respectively. For the scenario where all cells are classified as urban, the UCI-CIT model predicts LA County emissions of $0.65 \pm 0.22 \mathrm{Gg}$ and $1.12 \pm 0.29 \mathrm{Gg}$ for HFC- $152 \mathrm{a}$ and HFC-134a, respectively. For the SoCAB, the model predicts emissions of $1.08 \pm 0.20 \mathrm{Gg}$ and $1.53 \pm 0.21 \mathrm{Gg}$ for HFC-152a and HFC-134a, respectively. The uncertainty in the above estimates is the standard deviation of the emissions predicted by the six meteorological fields (see Supplement Table 2 for the emission rate generated by each meteorological field). Emissions estimates obtained using the AQM method differ from estimates derived by the tracer ratio method by less than $25 \%$ for LA County and less than $45 \%$ for the SoCAB.

There are some limitations in using the AQM method to obtain estimates of HFC emission rates: (1) although field measurements were obtained over a large area at many different elevations, it is possible that a disproportionate number of measurements were gathered over locations that have relatively low or high mixing ratios. Non-representative sampling could lead to incorrect predicted emission rates since the emission rates in the model were adjusted until mixing ratios from simulations match measured mixing ratios. However, non-representative sampling would affect the tracer ratio method as well; (2) in the simulations, it was assumed that the HFC emission rates were constant for all urban cells at all times. The true emission rates are not constant in time and may vary significantly among urban cells. This constant emission rate assumption was made to compare emissions determined from the AQM method to emissions determined by the tracer ratio method, which uses the 24-h average $\mathrm{CO}$ emission rate in LA County. Both methods assume a constant emission rate during all hours of the day; (3) actual wind fields during the June 2008 field campaign were similar, but not exactly the same, as the wind fields during the August 1987, September 1993, and October 1995 field campaigns, which were used in the simulations. The wind speed 
Table 4. A comparison of emissions estimates (in $\mathrm{Gg} \mathrm{yr}^{-1}$ ) of HFC-152a and HFC-134a from this study and previous studies.

\begin{tabular}{|c|c|c|c|c|}
\hline & LA County & SoCAB & US & Global \\
\hline \multicolumn{5}{|l|}{ HFC-152a } \\
\hline Tracer Ratio Method* & $0.82 \pm 0.11$ & $1.60 \pm 0.22$ & $32 \pm 4$ & \\
\hline AQM Method $* * *$ & $0.72 \pm 0.14 \mid 0.65 \pm 0.22$ & $0.91 \pm 0.20 \mid 1.08 \pm 0.20$ & & \\
\hline Stohl et al. (2009) ${ }^{\mathrm{a}}$ & & & 12.5 & \\
\hline Greally et al. $(2007)^{b}$ & & & & $28 \pm 4$ \\
\hline Millet et al. (2009) ${ }^{\mathrm{c}}$ & & & $7.6(5.7-9.7)^{* * *}$ & \\
\hline \multicolumn{5}{|l|}{ HFC-134a } \\
\hline Tracer Ratio Method* & $1.16 \pm 0.22$ & $2.12 \pm 0.28$ & $43 \pm 6$ & \\
\hline AQM Method $*, * *$ & $1.26 \pm 0.20 \mid 1.12 \pm 0.29$ & $1.29 \pm 0.21 \mid 1.53 \pm 0.21$ & & \\
\hline Stohl et al. $(2009)^{\mathrm{a}}$ & & & 28 & 156 \\
\hline Millet et al. $(2009)^{\mathrm{c}}$ & & & $27(12-39)^{* * *}$ & \\
\hline Manning and Weiss $(2007)^{\mathrm{d}}$ & & & $43(22-60)^{* * *}$ & \\
\hline
\end{tabular}

* This study; ${ }^{* *}$ left value from AQM method uses USGS land-use data from the 1970s. Right value assumes all cells are urban; *** values in parentheses are the minimum and maximum values reported in that study; ${ }^{a}$ US Estimates are for 2006. Global estimates are for the 2005-2006 period; ${ }^{b}$ estimates are for 2004 ; ${ }^{c}$ estimates are for the $2004-2006$ period; ${ }^{\mathrm{d}}$ estimates are for 2006.

during the June 2008 field campaign tends to be slightly higher than during the other three field campaigns, which has the effect of lowering predicted emission rates. If the wind is calmer, pollutants are removed from the SoCAB at a slower rate which lowers the emission rate needed to reproduce measured concentrations. However, although the June 2008 wind velocity is known for several locations in the So$\mathrm{CAB}$, the wind velocity at most locations is not known and would have to be estimated for most of the SoCAB, creating additional uncertainties in the predictions.

Despite these caveats, it appears that the emissions estimates from air quality simulations are credible since (1) the predicted emissions of HFC-152a and HFC-134a in LA County and the SoCAB determined from the AQM method are quite similar to estimates determined from the tracer ratio method and (2) most field measurements are within a factor of two of the mean concentration predicted in the LA area and SoCAB.

\section{Conclusions}

During the ARCTAS-CARB flights slightly elevated concentrations of many banned halocarbon species were observed over the SoCAB, including CFCs (Table 2). Much larger enhancements were observed for CFC replacements (HCFCs and HFCs), which demonstrates the strong influence that the Montreal Protocol and subsequent amendments has on reducing the use of potent ozone-depleting species. In the nearfuture, it is expected that the HCFC enhancements in the So$\mathrm{CAB}$ will decline as these species are phased-out in favor of HFCs and other species that have negligible ozone-depleting potential.
The issue of reducing GHG emissions is especially important in California as the state legislature passed legislation in 2006 that requires the CARB to develop policies to reduce California's greenhouse gas emissions to 1990 levels by 2020 . In order to fulfill this obligation, it is hoped that the results from this study can help CARB establish baseline emissions rates of potent GHG species, such as HFCs.

Two independent methods were employed to estimate the emissions of HFC-152a and HFC-134a from LA County and the SoCAB in 2008. The close agreement between the results lends credence to the emission estimates presented in this paper. Additionally, emissions estimates of the two HFCs in the US were derived by extrapolating the results from the tracer ratio method. For HFC-152a, the US emissions calculated in this work are higher than in previous studies, while the HFC-134a US emissions are in better agreement with previous studies.

\section{Supplementary material related to this article is available online at: http://www.atmos-chem-phys.net/11/2655/2011/ acp-11-2655-2011-supplement.pdf.}

Acknowledgements. The authors would like to thank the flight crew of the NASA DC-8 aircraft for their help during the field deployment, and Brent Love and Gloria Liu (University of California, Irvine) for technical support. This work was funded by the NASA Global Tropospheric Chemistry Program, the California Air Resources Board, and the United States National Science Foundation (Grant Nos. CHE-0431312 and ATM-0423804).

Edited by: A. Stohl 


\section{References}

ARCTAS, Earth Science Project Office, ARCTAS Home Page, National Aeronautics and Space Administration, available at: http://www.espo.nasa.gov/arctas/, last access: February 2011

Advanced Global Atmospheric Gases Experiment (AGAGE), Sponsored by NASA's Atmospheric Composition Focus Area in Earth Science, ALE/GAGE/AGAGE data (data up to March 2010 are available), http://cdiac.esd.ornl.gov/ftp/ale gage_Agage/AGAGE/gc-ms-medusa/monthly/, last access: October 2010.

Altshuller, A. P.: Average tropospheric concentration of carbon tetrachloride based on industrial production, usage, and emissions, Environ Sci. Technol., 10, 596-598, 1976.

Ashford, P., Clodic, D., McCulloch, A., and Kuijpers, L.: Emission profiles from the foam and refrigeration sectors comparison with atmospheric concentrations. Part 2: results and discussion, Int. J. Refrig., 27, 701-716, 2004.

Barletta, B., Meinardi, S., Simpson, I. J., Atlas, E. L., Beyersdorf, A. J., Baker, A. K., Blake, N. J., Yang, M., Midyett, J. R., Novak, B. J., McKeachie, R. J., Fuelberg, H. E., Sachse, G. W., Avery, M. A., Campos, T., Weinheimer, A. J., Rowland, F. S., and Blake, D. R.: Characterization of volatile organic compounds (VOCs) in Asian and north American pollution plumes during INTEX-B: identification of specific Chinese air mass tracers, Atmos. Chem. Phys., 9, 5371-5388, doi:10.5194/acp-9-5371-2009, 2009.

Barnes, D. H., Wofsy, S. C., Fehlau, B. P., Gottlieb, E. W., Elkins, J. W., Dutton, G. S., and Montzka, S. A.: Urban/industrial pollution for the New York City-Washington, D. C., corridor, 1996-1998: 2. A study of the efficacy of the Montreal Protocol and other regulatory measures, J. Geophys. Res., 108, 4186, doi:10.1029/2001JD001117, 2003.

Buchmann, B., Stemmler, K., and Reimann, S.: Regional emissions of anthropogenic halocarbons derived from continuous measurements of ambient air in Switzerland, Chimia, 57, 522-528, 2003.

Butler, J. H., Montzka, S. A., Clarke, A. D., Lobert, J. M., Elkins, J. W.: Growth and distribution of halons in the atmosphere, J. Geophys. Res., 103, 1503-1511, 1998.

California Air Resources Board (CARB): Emissions inventory data for 2008, available at: http://www.arb.ca.gov/ei/maps/statemap/ abmap.htm (last access: January 2011), 2008.

Colman, J. J., Swanson, A. L., Meinardi, S., Sive, B. C., Blake, D. R., and Rowland, F. S.: Description of the analysis of a wide range of volatile organic compounds in whole air samples collected during PEM- Tropics A and B, Anal. Chem., 73, 37233731, 2001.

European Commission (EC), Overview of HCFC consumption and available alternatives for Article 5 countries, available at: http://ec.europa.eu/environment/ozone/pdf/icf_hcfc background_doc.pdf (last access: September 2010), 2008.

European Parliament (EP): Directive 2006/40/EC of the European Parliament and of the Council, relating to emissions from air-conditioning systems in motor vehicles and amending Council Directive 70/156/EEC, available at: http://eur-lex.europa.eu/LexUriServ/site/en/oj/2006/1_161/ 1_16120060614en00120018.pdf, (last access: May 2010), 2006.

Forster, P., Ramaswamy, V., Artaxo, P., Berntsen, T., Betts, R., Fahey, D. W., Haywood, J., Lean, J., Lowe, D. C., Myhre, G., Nganga, J., Prinn, R.G., Raga, G., Schulz, M., van Dorland, R.: Changes in Atmospheric Constituents and in Radiative Forcing, in: Climate Change 2007: The Physical Science Basis, edited by: Solomon, S., Qin, D., Manning, M., Chen, Z., Marquis, M., Averyt, K. B., Tignor, M., and Miller, H. L., Contribution of Working Group I to the Fourth Assessment Report of the Intergovernmental Panel on Climate Change, Cambridge University Press, Cambridge, United Kingdom, 2007.

Greally, B. R., Manning, A. J., Reimann, S., McCulloch, A., Huang, J., Dunse, B. L., Simmonds, P. G., Prinn, R. G., Fraser, P. J., Cunnold, D. M. O’Doherty, S., Porter, L. W., Stemmler, K., Vollmer, M. K., Lunder, C. R., Schmidbauer, N., Hermansen, O., Arduini, J., Salameh, P. K., Krummel, P. B., Wang, R. H. J., Folini, D., Weiss, R. F., Maione, M., Nickless, G., Stordal, F., and Derwent, R. G.: Observations of 1,1-difluoroethane (HFC-152a) at AGAGE and SOGE monitoring stations in 1994-2004 and derived global and regional emission estimates, J. Geophys. Res., 112, D06308, doi:10.1029/2006JD007527, 2007.

Griffin, R. J., Dabdub, D. and Seinfeld, J. H.: Secondary organic aerosol: 1. Atmospheric chemical mechanism for production of molecular constituents, J. Geophys. Res., 107, 4332, doi:10.1029/2001JD000541, 2002a.

Griffin, R. J., Dabdub, D., Kleeman, M. J., Fraser, M. P., Cass, G. R., and Seinfeld J. H.: Secondary organic aerosol: 3. Urban/regional scale model of size- and composition-resolved aerosols, J. Geophys. Res., 107, 4334, doi:10.1029/2005JD006785, 2002b.

Hurst, D. F., Lin, J. C., Romashkin, P. A., Daube, B. C., Gerbig, C., Matross, D. M., Wofsy, S. C., Hall, B. D., and Elkins, J. W.: Continuing global significance of emissions of Montreal protocolrestricted halocarbons in the United States and Canada, J. Geophys. Res., 111, D15302, doi:10.1029/2005JD006785, 2006.

Jacob, D. J., Crawford, J. H., Maring, H., Clarke, A. D., Dibb, J. E., Emmons, L. K., Ferrare, R. A., Hostetler, C. A., Russell, P. B., Singh, H. B., Thompson, A. M., Shaw, G. E., McCauley, E., Pederson, J. R., and Fisher, J. A.: The Arctic Research of the Composition of the Troposphere from Aircraft and Satellites (ARCTAS) mission: design, execution, and first results, Atmos. Chem. Phys., 10, 5191-5212, doi:10.5194/acp-10-5191-2010, 2010.

Kim, J., Li, S., Kim, K.-R., Stohl, A., Mühle, J., Kim, S.-K., Park, M.-K., Kang, D.-J., Lee, G., Harth, C. M., Salameh, P. K., and Weiss, R. F.: Regional atmospheric emissions determined from measurements at Jeju Island, Korea: Halogenated compounds from China, Geophys. Res. Lett., 37, L12801, doi:10.1029/2010GL043263, 2010.

Knipping, E. M. and Dabdub, D.: Impact of altering $\mathrm{NO} / \mathrm{NO}_{2}$ splits in $\mathrm{NO}_{\mathrm{x}}$ emissions of diesel sources. Report prepared for the California Air Resources Board and the California Environmental Protection Agency, ARB Contract 01-331, 13 May 2002.

Li, J., Cunnold, D. M., Wang, H.-J., Weiss, R. F., Miller, B. R., Harth, C., Salameh, P., and Harris, J. M.: Halocarbon emissions estimated from advanced global atmospheric gases experiment measured pollution events at Trinidad Head, California, J. Geophys. Res., 110, D14308, doi:10.1029/2004JD005739, 2005.

Liu, H., Jacob, D. J., Bey, I., Yantosca, R. M., and Duncan, B. N.: Transport pathways for Asian pollution outflow over the Pacific: interannual and seasonal variations, J. Geophys. Res., 108, 8786, doi:10.1029/2002JD003102, 2003.

Logan, J. A., Prather, M. J., Wofsy, S. C., and McElroy, M. B.: Tropospheric chemistry: a global prospective, J. Geophys. Res., 86, 7210-7254, 1981. 
Maione, M., Giostra, U., Arduini, J., Belfiore, L., Furlani, F., Geniali, A., Mangani, G., Vollmer, M. K., and Reimann, S.: Localization of source regions of selected hydrofluorocarbons combining data collected at two European mountain stations, Sci. Total Environ., 391, 232-240, 2008.

Manning, A. J. and Weiss, R. F.: Quantifying Regional GHG Emissions from Atmospheric Measurements: HFC-134a at Trinidad Head. 50th Anniversary of the Global Carbon Dioxide Record Symposium and Celebration, Kona, Hawaii, available at: http://www.esrl.noaa.gov/gmd/co2conference/pdfs/ quantifying_abstract.pdf (last access: July 2010), 2007.

McCulloch, A., Ashford, P., and Midgley, P. M.: Historic emissions of fluorotrichloromethane (CFC-11) based on a market survey, Atmos. Environ., 35, 4387-4397, 2001.

McCulloch, A., Midgley, P. M., and Ashford, P.: Releases of refrigerant gases (CFC-12, HCFC-22 and HFC-134a) to the atmosphere, Atmos. Environ., 37, 889-902, 2003.

Meng, Z., Dabdub, D., and Seinfeld, J. H.: Size-resolved and chemically resolved model or aerosol dynamics, J. Geophys. Res., 103, 3419, doi:10.1029/97JD02796, 1998.

Millet, D. B. and Goldstein, A. H.: Evidence of continuing methylchloroform emissions from the United States, Geophys. Res. Lett., 31, L17101, doi:10.1029/2004GL020166, 2004.

Millet, D. B., Atlas, E. L., Blake, D. R., Blake, N. J., Diskin, G. S., Holloway, J. S., Hudman, R. C., Meinardi, S., Ryerson, T. B., and Sachse, G. W.: Halocarbon emissions from the United States and Mexico and their global warming potential, Environ. Sci. Technol., 43, 1055-1060, 2009.

Papasavva, S., Luecken, D. J., Waterland, R. L., Taddonio, K. N., and Andersen, S. O.: Estimated 2017 refrigerant emissions of 2,3,3,3-tetrafluoropropene (HFC-1234yf) in the United States resulting from automobile air conditioning, Environ. Sci. Technol., 43, 9252-9259, 2009.

Parrish, D. D., Stohl, A., Forster, C., Atlas, E. L., Blake, D. R., Goldan, P. D., Kuster, W. C., and de Gouw, J. A.: Effects of mixing on evolution of hydrocarbon ratios in the troposphere, J. Geophys. Res., 112, D10S34, doi:10.1029/2006JD007583, 2007.

Reimann, S., Schaub, D., Weiss, A., Stemmler, K., and Hofer, P.: Estimated emissions of halogenated greenhouse gases by analysis of on-line measurements at a high Alpine station (Jungfraujoch). Non-CO2 Greenhouse Gases: Scientific Understanding, Control Options and Policy Aspects, Proceedings of the International Symposium, 3rd, Maastricht, The Netherlands, 21-23 January 2002, 571-572, 2002.

Reimann, S., Schaub, D., Stemmler, K., Folini, D., Hill, M., Hofer, P., Buchmann, B., Simmonds, P. G., Greally, B. R., and O'Doherty, S.: Halogenated greenhouse gases at the Swiss high Alpine site of Jungfraujoch (3580 m a.s.1.): Continuous measurements and their use for regional European source allocation, J. Geophys. Res., 109, D05307, doi:10.1029/2003JD003923, 2004.

Reimann, S., Manning, A. J., Simmonds, P. G., Cunnold, D. M., Wang, R. H. J., Li, J., McCulloch, A., Prinn, R. G., Huang, J., Weiss, R. F., Fraser, P. J., O’Doherty, S., Greally, B. R., Stemmler, K., Hill, M., and Folini, D.: Low European methyl chloroform emissions inferred from long-term atmospheric measurements, Nature, 433, 506-508, 2005.

Sachse, G., Hill, G., Wade, L., and Perry, M.: Fast-response, highprecision carbon monoxide sensor using a tunable diode laser absorption technique, J. Geophys. Res., 92, 2071-2081, 1987.
South Coast Air Quality Management District (SCAQMD) website, available at: http://www.aqmd.gov/map/mapaqmd1.pdf (last access: May 2010), 2008.

Stohl, A., Seibert, P., Arduini, J., Eckhardt, S., Fraser, P., Greally, B. R., Lunder, C., Maione, M., Mühle, J., O’Doherty, S., Prinn, R. G., Reimann, S., Saito, T., Schmidbauer, N., Simmonds, P. G., Vollmer, M. K., Weiss, R. F., and Yokouchi, Y.: An analytical inversion method for determining regional and global emissions of greenhouse gases: Sensitivity studies and application to halocarbons, Atmos. Chem. Phys., 9, 1597-1620, doi:10.5194/acp9-1597-2009, 2009.

Sturrock, G. A., Etheridge, D. M., Trudinger, C. M., Fraser, P. J., and Smith, A. M.: Atmospheric histories of halocarbons from analysis of Antarctic firn air: Major Montreal Protocol species, J. Geophys. Res., 107, 4765-4778, 2002.

Talbot, R., Dibb, J., Scheuer, E., Seid, G., Russo, R., Sandholm, S., Tan, D., Singh, H., Blake, D., Blake, N., Atlas, E., Sachse, G., Jordan, C., and Avery, M.: Reactive nitrogen in Asian continental outflow over the western Pacific: results from the NASA transport and chemical evolution over the Pacific (TRACE-P) airborne mission, J. Geophys. Res., 108, 8803, doi:10.1029/2002JD003129, 2003.

United Nations Environment Programme (UNEP), United Nations Environment Programme (UNEP), Handbook for the International treaties for the protection of the ozone layer, $6^{\text {th }}$ edition. Nairobi, Kenya, available at: http://www.unep.org/ozone/pdfs/ handbook-2003.pdf (last access: July 2010), 2003.

United States Census Bureau, State \& County QuickFacts, available at: http://quickfacts.census.gov/qfd/states/06/06037.html (last access: May 2010), 2009.

U.S. Census Bureau, "Statistical Abstract of the United States: 2011", available at: http://www.census.gov/prod/2011pubs/ 11statab/pop.pdf, 2011.

Velders, G. J. M., Fahey, D. W., Daniel, J. S., McFarland, M., and Andersen, S. O.: The large contribution of projected HFC emissions to future climate forcing, P. Natl. Acad. Sci. USA, 106, 10949-10954, 2009.

Wimberger, E.: Emissions of HFC-134a in Auto Dismantling and Recycling. Report prepared for the State of California Air Resources Board, Contract Number 06-334, revised on 16 July, 2010.

World Meteorological Organization (WMO): Scientific assessment of ozone depletion: 2006. Global Ozone Research and Monitoring Project - Report No. 50, Geneva, Switzerland, available at: http://www.esrl.noaa.gov/csd/assessments/ozone/2006 (last access: July 2010), 2007.

Xiao, Y., Jacob, D. J., and Turquety, S.: Atmospheric acetylene and its relationship with $\mathrm{CO}$ as an indicator of air mass age, J. Geophys. Res., 112, D12305, doi:10.1029/2006JD008268, 2007.

Yokouchi, Y., Taguchi, S., Saito, T., Tohjima, Y., Tanimoto, H., and Mukai, H.: High frequency measurements of HFCs at a remote site in east Asia and their implications for Chinese emissions, Geophys. Res. Lett., 33, L21814, doi:10.1029/2006GL026403, 2006.

Wang, J. X. L. and Angell, J. K.: Air Stagnation Climatology for the United States (1948-1998), NOAA/Air Resources Laboratory ATLAS No. 1, available at: http://www.arl.noaa.gov/documents/ reports/atlas.pdf, 1999. 